\title{
Identification and Specificity Studies of Small- Molecule Ligands for SH3 Protein Domains
}

Steven R. Inglis, ${ }^{\dagger \neq}$ Cvetan Stojkoski, ${ }^{\dagger}$ Kim M. Branson, ${ }^{\dagger \S}$ Jacquie F. Cawthray, ${ }^{\ddagger}$ Daniel Fritz, ${ }^{\ddagger}$ Emma Wiadrowski, Simon M. Pyke, ${ }^{+}$and Grant W. Booker ${ }^{\dagger *}$

School of Molecular and Biomedical Science, and School of Chemistry and Physics, The University of Adelaide, SA, 5005, Australia.

* To whom correspondence should be addressed. Tel +61 883033090 .

Fax: +61 88303 4362. E-mail: grant.booker@adelaide.edu.au

${ }^{\dagger}$ School of Molecular and Biomedical Science

\$ School of Chemistry and Physics

$\S$ Current Address: CSIRO Division of Health Science and Nutrition, 343 Royal Parade, Parkville, Vic, 3050, Australia.

\section{Supporting Information}

TABLE S-1: Summary of Elemental Analyses

\begin{tabular}{cccc}
\hline Compound & Formula & Calculated: $\mathrm{C}, \mathrm{H}, \mathrm{N}:$ & Found: $\mathrm{C}, \mathrm{H} . \mathrm{N}:$ \\
\hline $\mathbf{1 4}$ & $\mathrm{C}_{17} \mathrm{H}_{17} \mathrm{NO}_{3}$ & $72.07,6.05,4.94$ & $72.12,5.91,4.94$ \\
$\mathbf{2 8}$ & $\mathrm{C}_{10} \mathrm{H}_{6} \mathrm{ClNO}$ & $62.68,3.16,7.31$ & $62.95,3.19,7.15$ \\
$\mathbf{3 2}$ & $\mathrm{C}_{12} \mathrm{H}_{10} \mathrm{ClNO}_{2}$ & $61.16,4.28,5.94$ & $61.02,4.39,5.91$ \\
$\mathbf{3 3}$ & $\mathrm{C}_{12} \mathrm{H}_{12} \mathrm{~N}_{2} \mathrm{O}_{2}$ & $66.65,5.5912 .96$ & $66.61,5.64,12.76$ \\
$\mathbf{3 6}$ & $\mathrm{C}_{13} \mathrm{H}_{12} \mathrm{ClNO}_{2}$ & $62.53,4.84,5.61$ & $62.53,4.89,5.53$. \\
$\mathbf{3 7}$ & $\mathrm{C}_{15} \mathrm{H}_{16} \mathrm{ClNO}_{2}$ & $64.87,5.81,5.04$ & $64.77,6.08,4.91$ \\
$\mathbf{3 8}$ & $\mathrm{C}_{13} \mathrm{H}_{14} \mathrm{~N}_{2} \mathrm{O}_{2}$ & $67.81,6.13,12.17$ & $67.20,6.14,11.86$ \\
$\mathbf{3 9}$ & $\mathrm{C}_{15} \mathrm{H}_{18} \mathrm{~N}_{2} \mathrm{O}_{2}$ & $69.74,7.02,10.84$ & $69.70,7.14,10.92$ \\
\hline
\end{tabular}




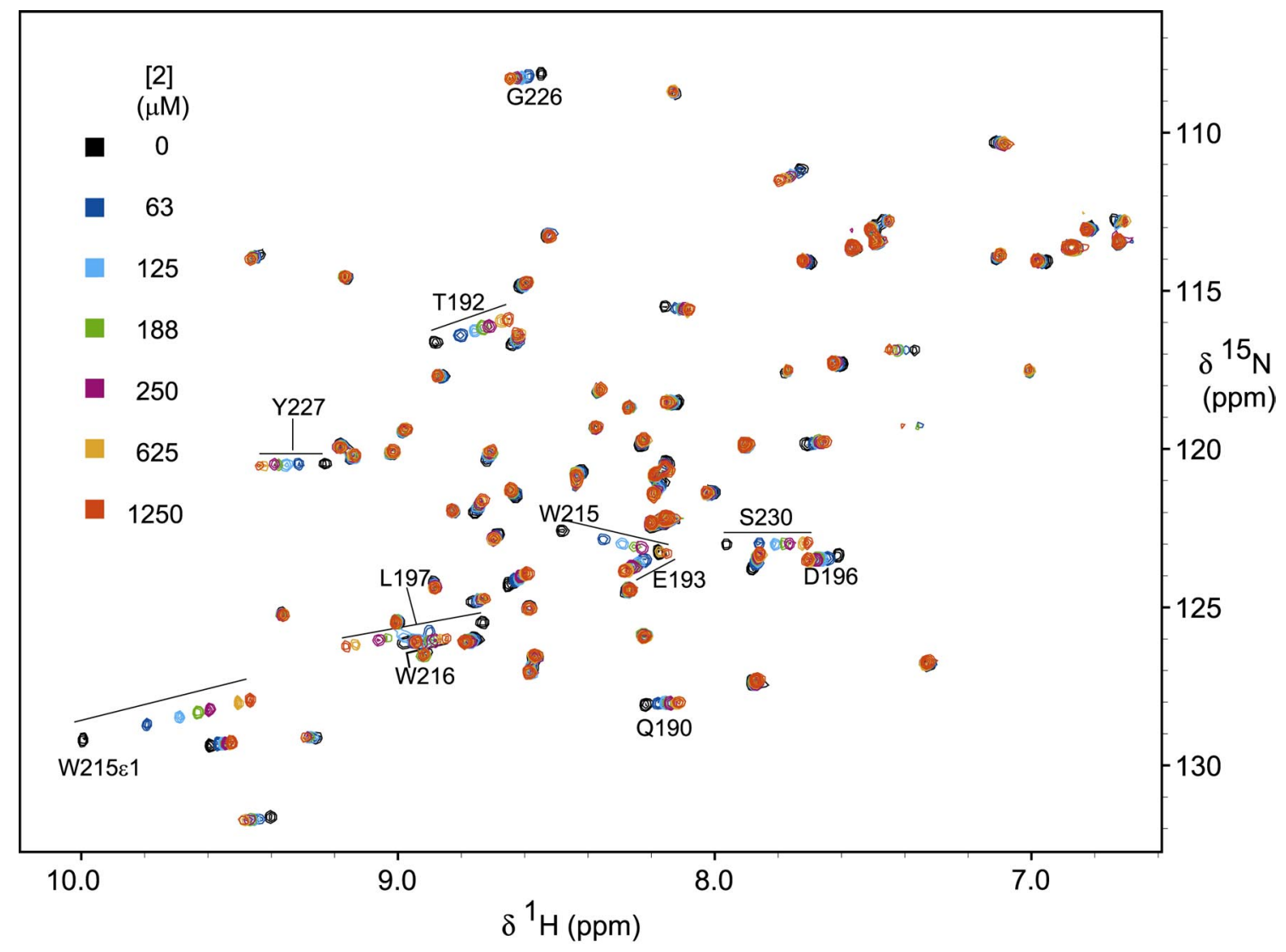

Figure S-1: Overlay of $\left[{ }^{1} \mathrm{H},{ }^{15} \mathrm{~N}\right]-\mathrm{HSQC}$ plots for uniformly ${ }^{15} \mathrm{~N}$ labelled Tec SH3 protein in presence of increasing concentration of 2-aminoquinoline 2. Experimental details are found in main paper. The labeled residues indicate those where $\Delta \delta{ }^{1} \mathrm{H}(\mathrm{H}-\mathrm{N}) \geq 0.1 \mathrm{ppm}$ when [2] = $1250 \mu \mathrm{M}$. 


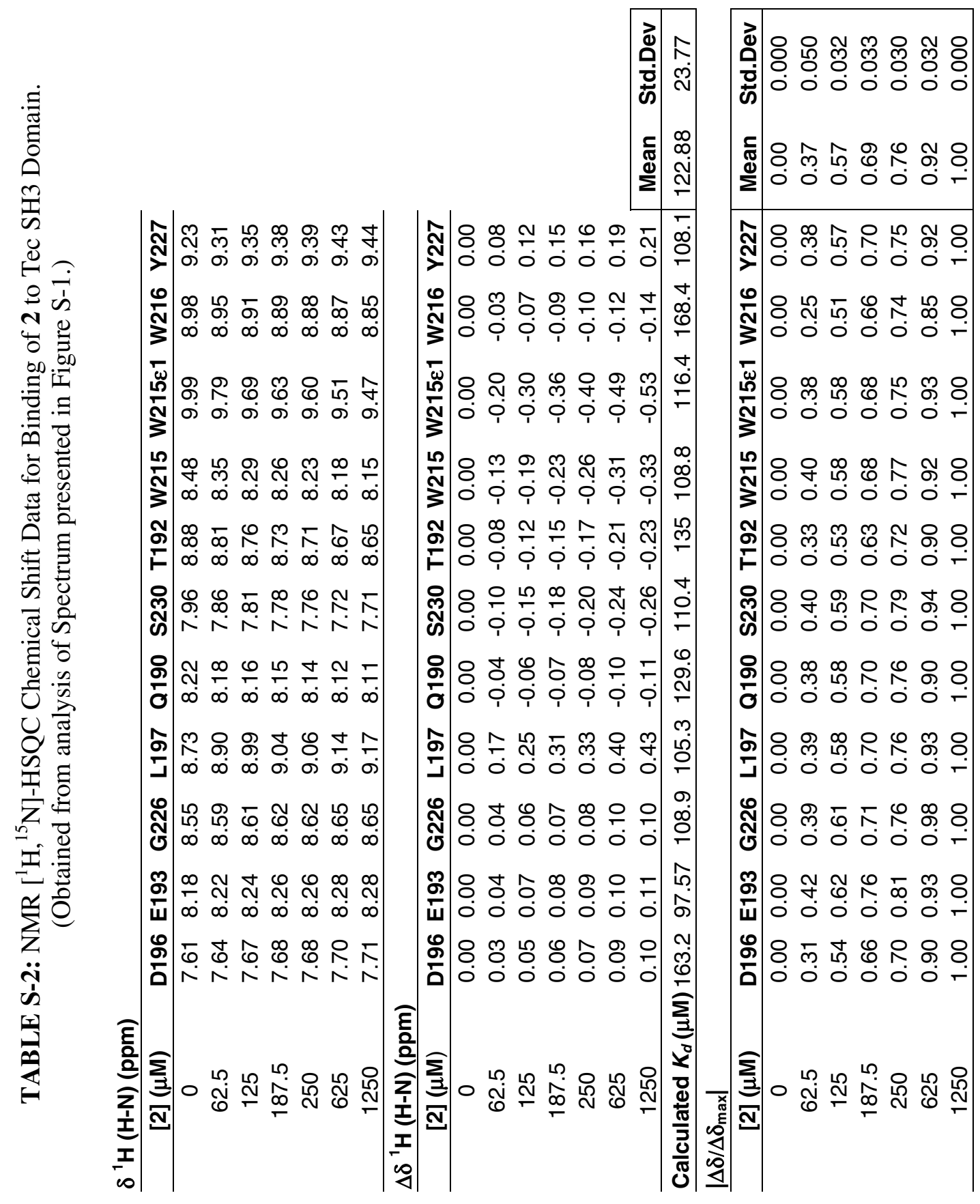



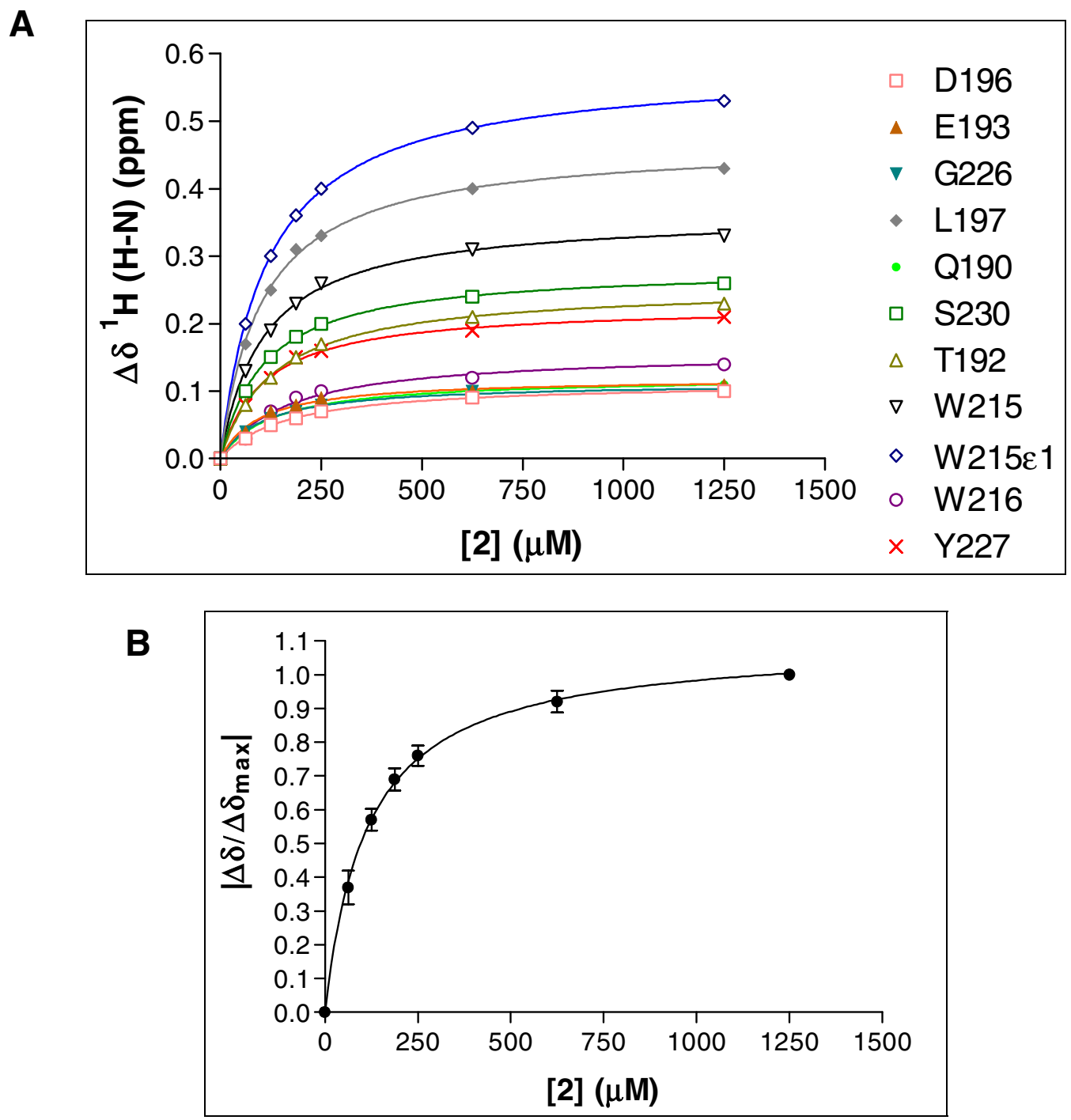

Figure S-2: Equilibrium binding of 2 to Tec SH3 domain as represented by change in ${ }^{1} \mathrm{H}(\mathrm{H}-$ $\mathrm{N})$ chemical shift from $\left[{ }^{1} \mathrm{H},{ }^{15} \mathrm{~N}\right]$-HSQC NMR experiments. (A) Binding isotherms for aminoacid residues where $\Delta \delta \geq 0.1 \mathrm{ppm}$ at close to saturation binding of 2 . (B) Binding isotherm represented by averaging the normalized chemical shift changes $\left|\Delta \delta / \Delta \delta_{\max }\right|$ calculated for all residues where $\left|\Delta \delta_{\max }\right| \geq 0.1 \mathrm{ppm}$. (See Table S-2). 


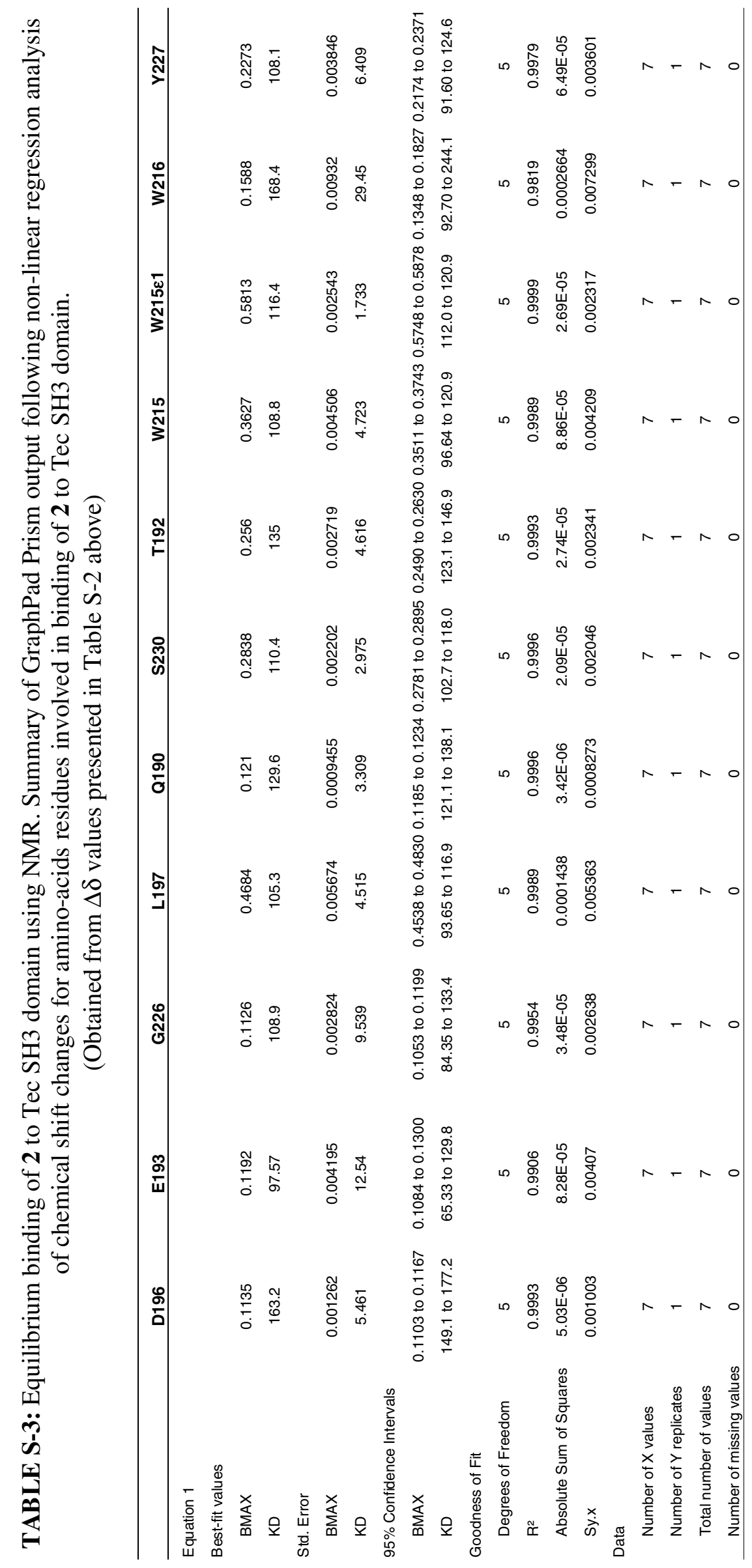




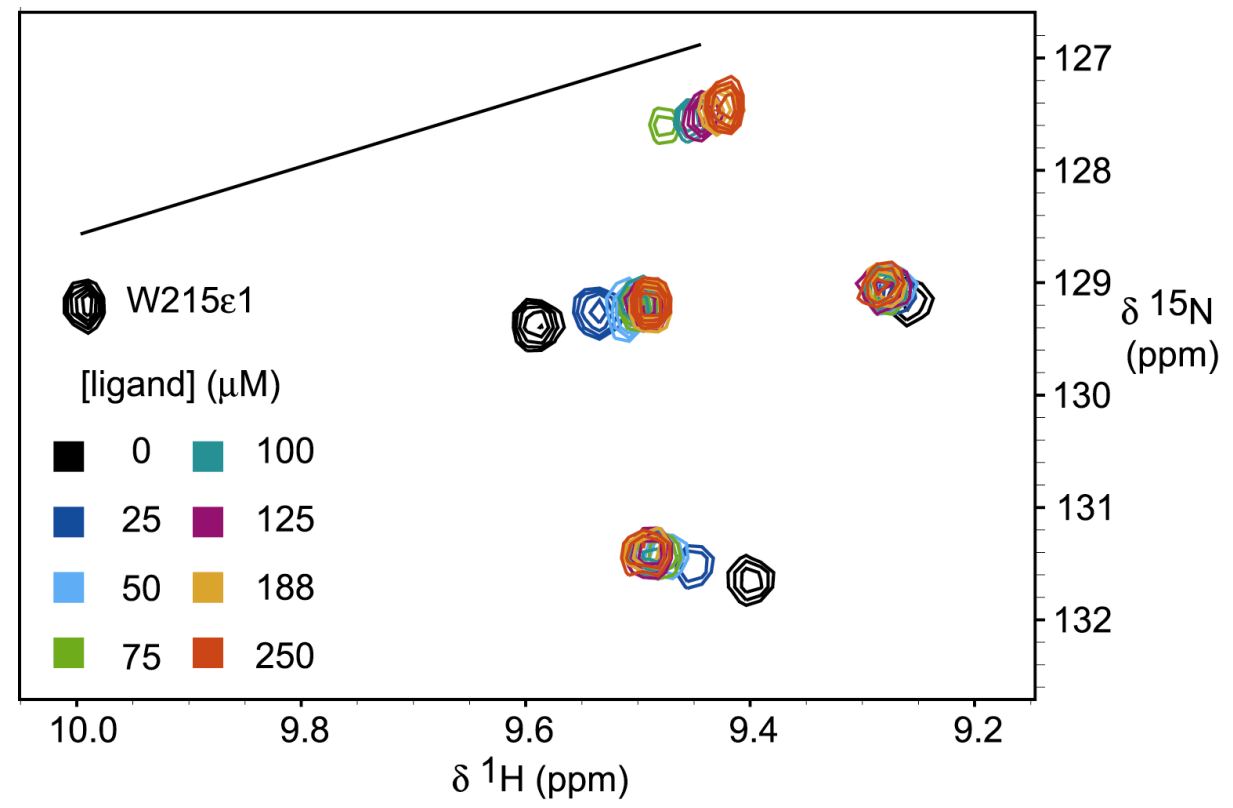

Figure S-4: A Region of $\left[{ }^{1} \mathrm{H},{ }^{15} \mathrm{~N}\right] . \mathrm{HSQC}$ overlays for uniformly labeled Tec SH3 protein with increasing concentrations of ligand 39. The region selected highlights the intermediate exchange nature of the signal for $\mathrm{W} 215 \varepsilon 1$ as illustrated by loss of the H-N cross peak at [39] $=25$ and $50 \mu \mathrm{M}$, the reappearance of the signal at [39] $=75 \mu \mathrm{M}$ although at lower intensity, followed by the return of the signal to full intensity at $100 \mu \mathrm{M}$ and the higher concentrations. The remaining signals in the region all display the fast exchange regime over the range of concentrations.

TABLE S-4: Fluorescence Polarization (FP) Data for PRP-1 Binding to Tec SH3 \& GSTSH3 Proteins. (For explanation of data analysis, see experimental section of main paper.)

\begin{tabular}{cccc}
\hline $\begin{array}{c}{[\mathbf{S H 3}]} \\
(\mu \mathbf{M})\end{array}$ & $\begin{array}{c}\text { Polarisation } \\
(\mathbf{m P})\end{array}$ & $\Delta \mathbf{m P}$ & Stdev of Replicates \\
\hline & & & \\
0 & 90.707 & 0.000 & 0.283 \\
5 & 91.913 & 1.206 & 0.772 \\
10 & 95.425 & 4.717 & 1.151 \\
25 & 101.239 & 10.531 & 1.238 \\
50 & 109.606 & 18.898 & 0.870 \\
100 & 122.418 & 31.710 & 0.830 \\
300 & 146.331 & 55.624 & 0.933 \\
490 & 155.956 & 65.249 & 1.152 \\
\hline & & & \\
\hline [GST-SH3] & Polarisation & $\Delta \mathbf{m P}$ & Stdev of Replicates \\
$(\mu \mathbf{M})$ & $(\mathbf{m P})$ & & \\
\hline & & & \\
0 & 82.430 & 0.000 & 1.424 \\
10 & 90.590 & 8.159 & 0.756 \\
25 & 101.991 & 19.561 & 1.666 \\
50 & 112.886 & 30.456 & 0.787 \\
132 & 136.558 & 54.127 & 0.397 \\
300 & 164.238 & 81.808 & 1.550 \\
400 & 171.885 & 89.455 & 1.520 \\
600 & 181.992 & 99.562 & 0.845 \\
\hline
\end{tabular}




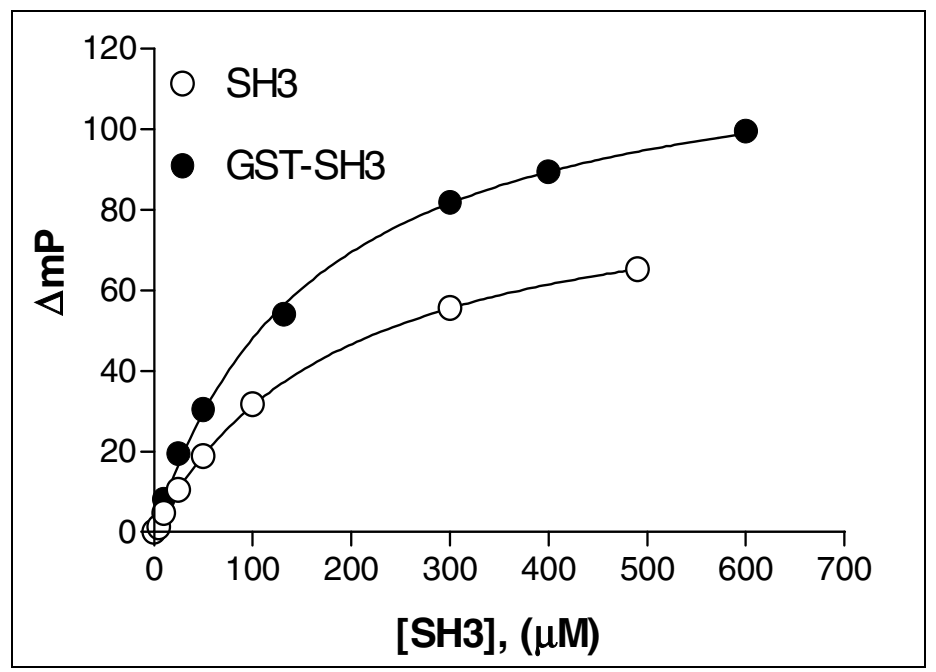

FIGURE S-5: Isotherms for equilibrium binding of either the free SH3 protein, or the GSTSH3 protein to fluorescently labeled proline rich peptide PRP-1 using FP. These graphs were generated from data presented in Table S-4 above.

TABLE S-5: Equilibrium binding of PRP-1 with Tec SH3 and GST-SH3 proteins using FP. Summary of Output from GraphPad Prism following non-linear regression from data in Table S-4, and curves in Figure S-5 above.

\begin{tabular}{lcc}
\hline Equation 1 & SH3 & GST-SH3 \\
\hline Best-fit values & & \\
$\quad$ BMAX & 90.27 & 125.5 \\
KD & 187.2 & 160.9 \\
Std. Error & 1.253 & 2.903 \\
$\quad$ BMAX & 6.226 & 10.47 \\
KD & & \\
95\% Confidence Intervals & 87.20 to 93.34 & 118.4 to 132.6 \\
BMAX & 171.9 to 202.4 & 135.2 to 186.5 \\
KD & & \\
Goodness of Fit & 6 & 6 \\
$\quad$ Degrees of Freedom & 0.9997 & 0.9986 \\
R & 1.437 & 14.65 \\
Absolute Sum of Squares & 0.4893 & 1.562 \\
Sy.X & & \\
Data & 8 & 16 \\
$\quad$ Number of X values & 1 & 1 \\
$\quad$ Number of Y replicates & 8 & 8 \\
$\quad$ Total number of values & 0 & 8 \\
$\quad$ Number of missing values & & \\
\hline
\end{tabular}




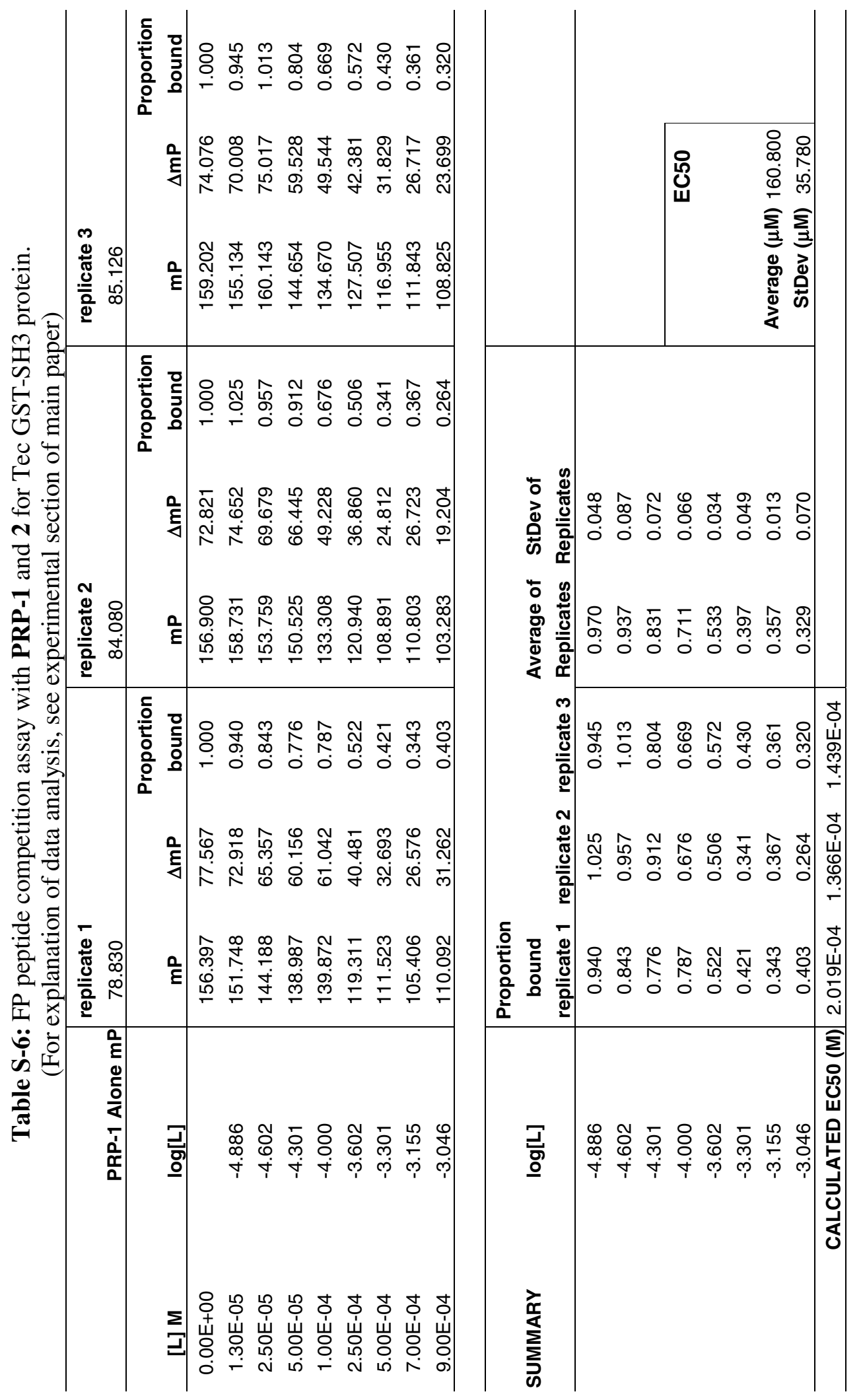



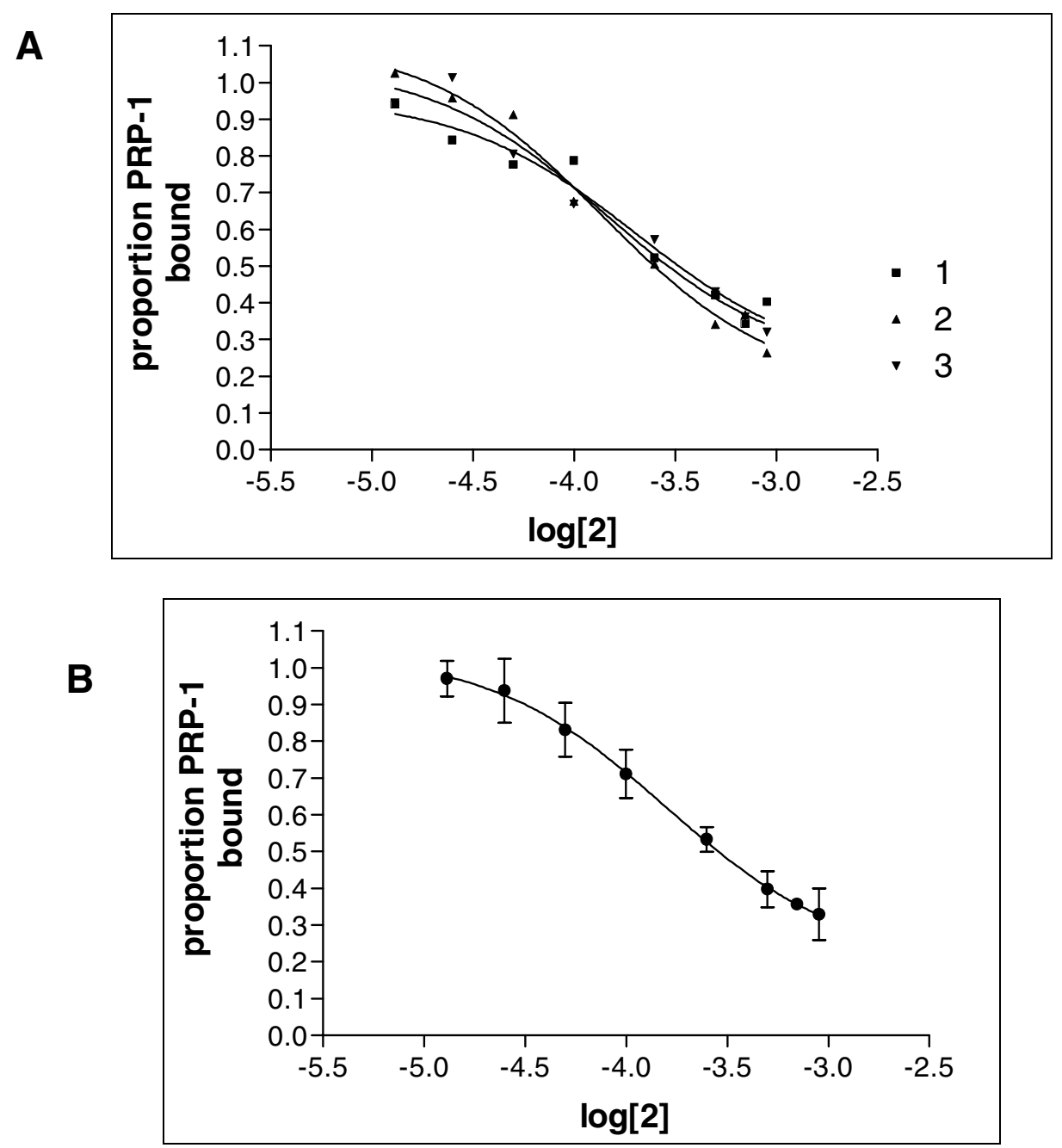

Figure S-6: FP peptide competition assay for PRP-1 and 2 for binding to Tec GST-SH3 protein. (A) Competition isotherm for individual replicate data sets produced from data presented in Table S-6 above. (B) Competition isotherm for average of replicates, produced from data presented in Table S-6 above. 
TABLE S-7: Summary of FP peptide competition assay with PRP-1 and $\mathbf{2}$ for binding to Tec SH3 domain. [Output obtained from non-linear regression analysis of data in Table S-6 and curves in Figure S-6 (A) above]

\begin{tabular}{|c|c|c|c|}
\hline & 1 & 2 & 3 \\
\hline \multicolumn{4}{|l|}{ Equation 1} \\
\hline \multicolumn{4}{|l|}{ Best-fit values } \\
\hline BOTTOM & 0.219 & 0.1623 & 0.2274 \\
\hline TOP & 0.9582 & 1.117 & 1.051 \\
\hline LOGEC50 & -3.695 & -3.865 & -3.842 \\
\hline EC50 & 0.0002019 & 0.0001363 & 0.0001439 \\
\hline \multicolumn{4}{|l|}{ Std. Error } \\
\hline ВОТTОМ & 0.0935 & 0.05327 & 0.07455 \\
\hline TOP & 0.05396 & 0.04864 & 0.06401 \\
\hline LOGEC50 & 0.2187 & 0.1201 & 0.189 \\
\hline \multicolumn{4}{|l|}{$95 \%$ Confidence Intervals } \\
\hline ВОTTOM & -0.02141 to 0.4594 & 0.02535 to 0.2993 & 0.03575 to 0.4191 \\
\hline TOP & 0.8195 to 1.097 & 0.9918 to 1.242 & 0.8868 to 1.216 \\
\hline LOGEC50 & -4.257 to -3.132 & -4.174 to -3.557 & -4.328 to -3.356 \\
\hline EC50 & $5.5300 \mathrm{e}-005$ to 0.0007371 & $6.6960 \mathrm{e}-005$ to 0.0002776 & $4.7010 \mathrm{e}-005$ to 0.0004405 \\
\hline \multicolumn{4}{|l|}{ Goodness of Fit } \\
\hline Degrees of Freedom & 5 & 5 & 5 \\
\hline $\mathrm{R}^{2}$ & 0.9643 & 0.9878 & 0.9706 \\
\hline Absolute Sum of Squares & 0.01345 & 0.007909 & 0.01438 \\
\hline Sy.x & 0.05187 & 0.03977 & 0.05362 \\
\hline \multicolumn{4}{|l|}{ Data } \\
\hline Number of $X$ values & 8 & 8 & 8 \\
\hline Number of $Y$ replicates & 1 & 1 & 1 \\
\hline Total number of values & 8 & 8 & 8 \\
\hline Number of missing values & 0 & 0 & 0 \\
\hline
\end{tabular}


TABLE S-8: FP peptide competition assay with PRP-1 and 2 for D196 mutants of Tec GST$\mathrm{SH} 3$ protein. For these experiments, the proportion bound terms presented are the calculated averages of the replicates. (Individual replicates not shown)

\begin{tabular}{|c|c|c|c|c|c|}
\hline \multicolumn{3}{|c|}{ D196A } & \multicolumn{3}{|c|}{ D196E } \\
\hline $\log [(2)]$ & proportion bound & Std Dev & $\log [(2)]$ & proportion bound & Std Dev \\
\hline-4.699 & 1.000 & 0.044 & -4.699 & 1.019 & 0.039 \\
\hline-4.301 & 1.026 & 0.029 & -4.301 & 1.103 & 0.046 \\
\hline-4.000 & 1.055 & 0.036 & -4.000 & 1.124 & 0.031 \\
\hline-3.824 & 1.041 & 0.032 & -3.824 & 1.017 & 0.042 \\
\hline-3.523 & 0.950 & 0.034 & -3.523 & 0.946 & 0.049 \\
\hline-3.301 & 0.922 & 0.024 & -3.301 & 0.988 & 0.039 \\
\hline-3.036 & 0.950 & 0.042 & -3.108 & 1.005 & 0.030 \\
\hline \multicolumn{3}{|c|}{ D196N } & \multicolumn{3}{|c|}{ D196T } \\
\hline $\log [(2)]$ & proportion bound & Std Dev & $\log [(2)]$ & proportion bound & Std Dev \\
\hline-4.699 & 0.984 & 0.025 & -4.699 & 0.930 & 0.028 \\
\hline-4.301 & 0.943 & 0.028 & -4.301 & 1.078 & 0.026 \\
\hline-4.000 & 0.982 & 0.019 & -4.000 & 0.963 & 0.036 \\
\hline-3.824 & 0.947 & 0.025 & -3.824 & 0.932 & 0.032 \\
\hline-3.523 & 0.917 & 0.018 & -3.602 & 0.830 & 0.012 \\
\hline-3.301 & 0.909 & 0.025 & -3.347 & 0.916 & 0.033 \\
\hline-3.066 & 0.958 & 0.025 & -3.123 & 0.924 & 0.014 \\
\hline
\end{tabular}

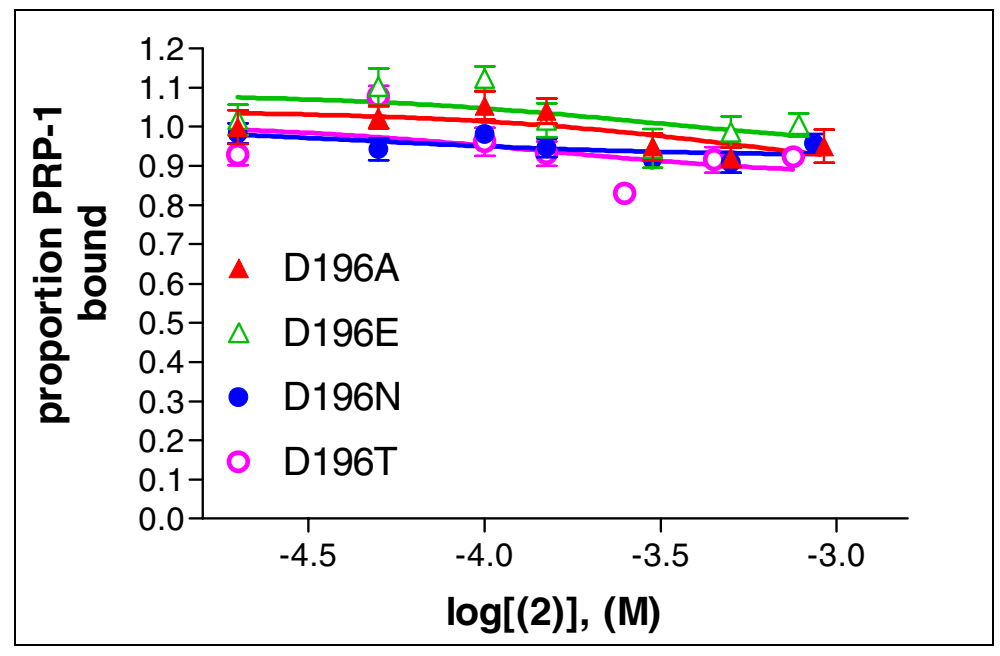

FIGURE S-7: FP peptide competition assay for PRP-1 and 2 for binding to Tec D196 mutant GST-SH3 proteins. Isotherms obtained following non-linear regression analysis of data presented in Table $\mathrm{S}-8$ above. 
TABLE S-9: Summary of Output from GraphPad Prism following non-linear regression analysis of data presented in Table S-8, and curves in Figure S-7 above. EC $_{50}$ values were all rejected based on quality of regression coefficient $R^{2}$.

\begin{tabular}{|c|c|c|c|c|}
\hline & D196A & D196E & D196N & D196T \\
\hline \multicolumn{5}{|l|}{ Equation 1} \\
\hline \multicolumn{5}{|l|}{ Best-fit values } \\
\hline вотТОМ & 0.8545 & 0.9371 & 0.9267 & 0.869 \\
\hline TOP & 1.041 & 1.084 & 1.003 & 1.011 \\
\hline LOGEC50 & -3.222 & -3.525 & -4.331 & -3.847 \\
\hline EC50 & 0.0005994 & 0.0003100 & $4.66 \mathrm{E}-05$ & 0.0001424 \\
\hline \multicolumn{5}{|l|}{ Std. Error } \\
\hline Воттом & 0.2209 & 0.2209 & 0.0274 & 0.1375 \\
\hline TOP & 0.03935 & 0.03935 & 0.09734 & 0.1248 \\
\hline LOGEC50 & 1.167 & 1.167 & 1.489 & 1.8 \\
\hline \multicolumn{5}{|l|}{ 95\% Confidence Intervals } \\
\hline воттом & 0.2414 to 1.468 & 0.3704 to 1.500 & 0.8506 to 1.003 & 0.4873 to 1.251 \\
\hline TOP & 0.9318 to 1.150 & 0.8766 to 1.291 & 0.7323 to 1.273 & 0.6641 to 1.357 \\
\hline LOGEC50 & -6.462 to 0.01687 & -8.338 to 1.321 & -8.465 to -0.1978 & -8.843 to 1.150 \\
\hline EC50 & \multicolumn{4}{|c|}{$3.4550 \mathrm{e}-007$ to $1.0404 .5910 \mathrm{e}-009$ to $20.933 .4310 \mathrm{e}-009$ to $0.63411 .4360 \mathrm{e}-009$ to 14.12} \\
\hline \multicolumn{5}{|c|}{$\mathrm{l}_{1}$} \\
\hline Degrees of Freedom & 4 & 4 & 4 & 4 \\
\hline $\mathrm{R}^{2}$ & 0.577 & 0.3351 & 0.3773 & 0.2523 \\
\hline Absolute Sum of Squares & 0.006765 & 0.01588 & 0.003151 & 0.02435 \\
\hline Sy.x & 0.04112 & 0.06301 & 0.02807 & 0.07802 \\
\hline \multicolumn{5}{|l|}{ Data } \\
\hline Number of $X$ values & 14 & 21 & 28 & 35 \\
\hline Number of Y replicates & 1 & 1 & 1 & 1 \\
\hline Total number of values & 7 & 7 & 7 & 7 \\
\hline Number of missing values & & 14 & 21 & 28 \\
\hline
\end{tabular}




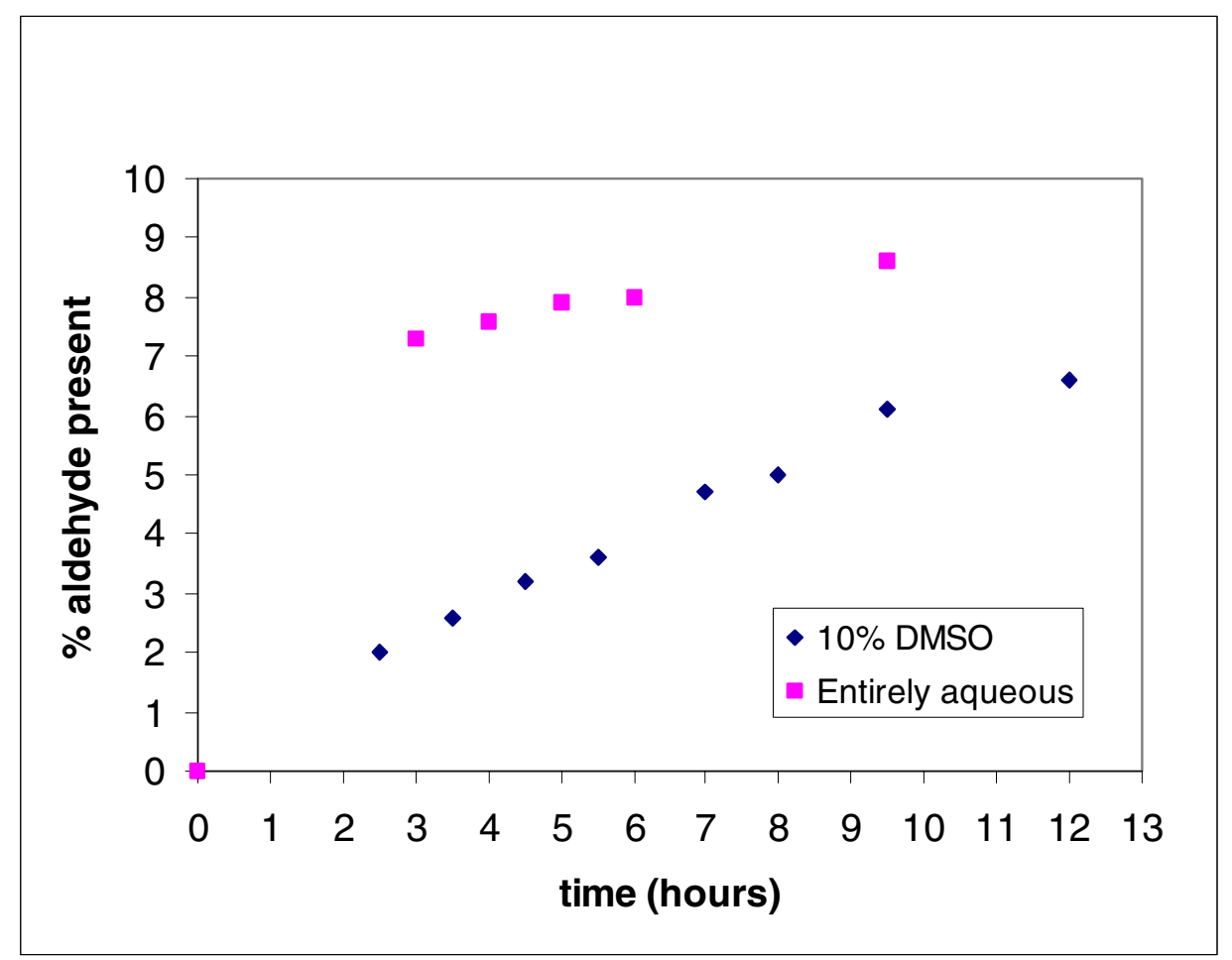

Figure S-8: Plot of percentage of 2-amino-6-formylquinoline 31 present in an aqueous sample of $\mathbf{3 3}$ with time, as determined by ${ }^{1} \mathrm{H}$ NMR. The blue series represents a sample of $\mathbf{3 3}$ $\left(1 \mathrm{mg}\right.$ ) dissolved in $0.5 \mathrm{~mL}$ of $10 \mathrm{mM} \mathrm{Na} 2 \mathrm{HPO}_{4}$ with $10 \% \mathrm{v} / \mathrm{v} \mathrm{d}_{6}-\mathrm{DMSO}$ and $10 \% \mathrm{v} / \mathrm{v} \mathrm{D}_{2} \mathrm{O}$ $\mathrm{pH}$ 6.5. The pink series represents a sample of $\mathbf{3 3}(1 \mathrm{mg})$ dissolved in $0.5 \mathrm{~mL}$ of $10 \mathrm{mM}$ $\mathrm{Na}_{2} \mathrm{HPO}_{4}$, with $10 \% \mathrm{v} / \mathrm{v} \mathrm{D}_{2} \mathrm{O}$ (heating of sample required to dissolve ligand). The percentage of aldehyde was calculated by comparing the relative integrations of signals for acetal proton with aldehyde proton. Spectra were recorded with low power presaturation of the residual water signal (HOD, $\delta 4.72$ ), a $90^{\circ}$ excitation pulse and a $10 \mathrm{~s}$ delay between transients. 